\title{
STUDI KASUS PEMANFAATAN TOGA DAN AKUPRESUR PROVINSI DKI JAKARTA TAHUN 2020
}

\author{
Gabe Gusmi Aprilla ${ }^{1}$, Rachmadhi Purwana ${ }^{2}$ \\ ${ }^{1}$ Magister of Public Health, Universitas Indonesia, Kampus Baru UI Depok 16424, Indonesia \\ ${ }^{2}$ Environment Department Faculty of Public Health Universitas Indonesia, D Building $2^{\text {nd }}$ floor Kampus Baru UI \\ Depok 16424, Indonesia \\ *Corresponding Author: Gabe Gusmi Aprilla, ${ }^{1}$ Magister of Public Health, Universitas Indonesia Kampus Baru UI \\ Depok 16424, Indonesia, E-mail: gabe.gusmi@gmail.com, \\ Phone: +6281218952980
}

\begin{abstract}
Abstrak
Sebelum berkembangnya pengobatan modern, masyarakat di dunia menggunakan pengobatan tradisional sebagai upaya memelihara kesehatan dan menyembuhkan penyakitnya. Di Indonesia bukti nenek moyang menggunakan bahan alam sebagai obat tradisional dari adanya naskah lama. Dalam sistem kesehatan nasional pemanfaatan TOGA dan Akupresur termasuk upaya pemberdayaan bersumber daya masyarakat (UKBM). TOGA merupakan sekumpulan tanaman berkhasiat obat untuk kesehatan keluarga yang ditata menjadi sebuah taman dan memiliki nilai keindahan. Sedangkan akupresur merupakan suatu prosedur melibatkan stimulasi titik-titik tertentu pada tubuh dengan tekanan

Penelitian ini menggunakan data sekunder dari laporan Riset Kesehatan Dasar Tahun 2018. Data dianalisa secara deskriptif dengan literatur review dengan tujuan mengetahui gambaran karakteristik masyarakat dalam pemanfaatan TOGA dan Akupresur di Provinsi DKI Jakarta.

Proporsi masyarakat Indonesia dalam memanfaatkan ramuan jadi 48\%, ramuan buatan sendiri 31,8\%, keterampilan manual $65,3 \%$, keterampilan olah pikir $1,9 \%$ dan keterampilan energi $2,1 \%$. Provinsi terbanyak memanfaatkan ramuan jadi Kalimantan Selatan 58,4\%, sedangkan provinsi terbanyak membuat ramuan sendiri Sulawesi Barat 85,5\%. Dalam hal memanfaatkan keterampilan manual terbanyak provinsi Kalimantan Selatan 83,3\%. Dalam hal pemanfaatan TOGA, masyarakat Provinsi Sulawesi Utara paling memanfaatkan TOGA sebesar $55,6 \%$, sedangkan masyarakat DKI Jakarta termasuk kurang memanfaatkan TOGA hanya 9,1\%. Masyarakat DKI Jakarta lebih banyak memanfaatkan ramuan jadi 59,6\% dibandingkan membuat ramuan sendiri 18,7\%, sedangkan untuk keterampilan manual termasuk banyak $68,6 \%$.

Untuk mendorong masyarakat lebih antuasias memanfaatkan TOGA dan Akupresur, maka perlu strategi seperti mengadakan pelatihan bagi petugas Puskesmas, kader dan masyarakat, perlombaan tingkat Nasional dan Provinsi, inovasi dan sosialisasi,
\end{abstract}

Kata kunci: pemanfaatan TOGA, Akupresur, pengobatan tradisional 


\section{Pendahuluan}

Sebelum berkembangnya pengobatan modern, masyarakat di dunia menggunakan pengobatan tradisional sebagai upaya memelihara kesehatan dan menyembuhkan penyakitnya. Menurut WHO pengobatan tradisional adalah gabungan dari pengetahuan, keterampilan, dan praktik yang didasarkan pada teori, kepercayaan, dan pengalaman yang berasal dari budaya yang berbeda, apakah dapat dijelaskan atau tidak, digunakan dalam pemeliharaan kesehatan serta dalam pencegahan, diagnosis, peningkatan atau pengobatan. penyakit fisik dan mental. Istilah "pengobatan komplementer" atau "pengobatan alternatif" mengacu pada serangkaian luas praktik perawatan kesehatan yang bukan bagian dari tradisi negara itu sendiri atau obat konvensional dan tidak sepenuhnya terintegrasi ke dalam sistem perawatan kesehatan yang dominan. Metode pengobatan komplementer digunakan secara bergantian dengan pengobatan tradisional di beberapa negara. Strategi WHO untuk membangun basis pengetahuan pengobatan tradisional komplementer (T\&CM), memperkuat jaminan kualitas $\mathrm{T} \& \mathrm{CM}$ dan mengintegrasikan pelayanan T\&CM ke dalam pelayanan kesehatan modern dituangkan ke dalam Strategi Pengobatan Tradisional 2014-2023[1].
Di Indonesia bukti nenek moyang menggunakan bahan alam sebagai obat tradisional dari adanya naskah lama pada daun lontar Husodo (Jawa), Usada (Bali), Lontarak pabbura (Sulawesi Selatan), dokumen Serat Primbon Jampi, Serat Racikan Boreh Wulang nDalem dan relief candi Borobudur yang menggambarkan orang sedang meracik obat (jamu) dengan tumbuhan sebagai bahan bakunya. Ap.[2]

alagi Indonesia menempati peringkat kedua dunia setelah Brasil dalam hal keanekaragaman hayati. Indonesia memiliki sekitar 30 ribu hingga 50 ribu jenis tumbuhan. Namun, hanya sekitar 7.500 yang dapat digunakan untuk tanaman obat. .[3]

Untuk meningkatkan akses pelayanan kesehatan tradisional berkualitas bagi masyarakat Pemerintah melakukan strategi dengan melaksanakan asuhan mandiri kesehatan tradisional pemanfaatan taman obat keluarga dan akupresur, melaksanakan kegiatan pengumpulan data kesehatan tradisional, fasilitasi registrasi/perizinan dan bimbingan teknis serta pemantauan pelayanan kesehatan tradisional. Juga melatih dokter, perawat, bidan dan fisioterapi Puskesmas yang terkait pelayanan kesehatan tradisional. Strategi ini dituangkan ke dalam Rencana Strategi Kementerian Kesehatan. .[4] 
Dalam sistem kesehatan nasional pemanfaatan TOGA dan Akupresur termasuk upaya pemberdayaan bersumber daya masyarakat (UKBM). TOGA merupakan sekumpulan tanaman berkhasiat obat untuk kesehatan keluarga yang ditata menjadi sebuah taman dan memiliki nilai keindahan. Dikaitkan dengan peran masyarakat, TOGA merupakan wujud partisipasi masyarakat dalam bidang peningkatan kesehatan dan pengobatan sederhana dengan memanfaatkan TOGA. Fungsi utama dari TOGA adalah menghasilkan tanaman yang dapat dipergunakan antara lain untuk menjaga dan meningkatkan kesehatan dan mengobati gejala (keluhan) dari beberapa penyakit yang ringan. Selain itu TOGA juga berfungsi ganda mengingat dapat digunakan untuk memperbaiki gizi masyarakat, upaya pelestarian alam dan memperindah pemandangan, menambah penghasilan keluarga dan memperindah taman dan pemandangan. .[5] Sedangkan akupresur merupakan suatu prosedur melibatkan stimulasi titik-titik tertentu pada tubuh dengan tekanan [6].Sedangkan menurut Putu akupresur merupakan ilmu penyembuhan dengan menekan, memijat dan mengurut pada bagian tubuh tertentu dengan bantuan jari, tangan atau bagian tubuh lain atau benda tumpul untuk mengembalikan energi vital atau chi .[7]

Saat ini Pemerintah mendorong masyarakat memanfaatkan pelayanan kesehatan tradisional pemanfaatan TOGA dan Akupresur secara mandiri yang dikenal dengan istilah asuhan mandiri (asman). Dengan melakukan asuhan mandiri (asman) berarti kita telah berupaya mengubah paradigma pengobatan kuratif menjadi promotif dan preventif yang bermanfaat untuk efisiensi dan efektifitas bagi keluarga dalam menjaga kesehatan diri sendiri dan keluarga, sehingga kunjungan ke Puskesmas merupakan kunjungan dalam rangka konsultasi kesehatan bukan untuk mengobati sakitnya. Upaya pemanfaatan TOGA dan Akupresur secara mandiri diatur dalam Peraturan Menteri Kesehatan Republik Indonesia Nomor 9 Tahun 2016 tentang Upaya Pengembangan Kesehatan Tradisional Melalui Asuhan Mandiri Pemanfaatan Taman Obat Keluarga dan Keterampilan.

Dengan diterbitkannya Permenkes No 9 Tahun 2016, maka program UKMB pemanfaatan TOGA dan Akupresur sebagai wahana pemberdayaan masyarakat yang dibentuk atas dasar kebutuhan masyarakat dikelola dari, oleh, untuk dan bersama masyarakat dengan bimbingan dari Petugas Puskesmas, lintas sektor dan lembaga terkait lainnya. Upaya pengembangan pemanfaatan TOGA dan Akupresur diselenggarakan melalui pembentukan dan pengembangan kelompok asuhan mandiri, kegiatan kelompok asuhan mandiri secara berkesinambungan dan pembinaan secara berjenjang oleh Kementerian Kesehatan, Dinas Kesehatan 
Provinsi, Dinas Kesehatan Kabupaten/Kota dan Puskesmas dan dilakukan secara bersama antar lintas program kementerian dan lintas sektor kementerian terkait. Di tingkat kecamatan, kegiatan UKMB pemanfaatan TOGA dan Akupresur dilakukan oleh Kepala Puskesmas bersama fasilitator terlatih kepada pemangku kepentingan serta masyarakat di wilayah kerjanya. Tugas fasilitator Puskesmas Kecamatan pertama melakukan orientasi kepada kader tentang asuhan mandiri pemanfaatan TOGA dan Akupresur sebagai dasar pengetahuan dalam melaksanakan tugas untuk membina/melatih keluarga binaan yang akan menjadi kelompok asuhan mandiri, berkoordinasi dengan pihak terkait. Kedua memfasilitasi kader dalam pembentukan dan pengembangan kelompok asuhan mandiri pemanfaatan TOGA dan Akupresur, ketiga mendampingi kader bersama tim penggerak PKK, Pertanian dan lintas sektor lainnya dalam kegiatan asuhan mandiri pemanfaatan TOGA dan Akupresur di wilayah kerjanya. Keempat memantau secara periodik atas pelaksanaan kegiatan asuhan mandiri pemanfaatan TOGA dan Akupresur diwilayah kerjanya agar kegiatan dapat berlangsung dengan baik sesuai dengan tujuan yang telah ditetapkan dan terakhir menjemput catatan kader tentang pelaksanaan kegiatan kelompok asuhan mandiri setiap bulannya dan melaporkan ke Dinas Kesehatan setiap triwulan.
Dalam melakukan kegiatan asuhan mandiri mesti memenuhi persyaratan aman, sesuai norma, praktis dan masing-masing keluarga berpartisipasi aktif. Kegiatan di kelompok sesuai dengan kebutuhan kelompok, minimal satu bulan sekali, dipimpin oleh kader dan didampingi oleh fasilitator Puskesmas dan mitra. Setiap keluarga dalam kelompok mempelajari dan melaksanakan cara pengelolaan TOGA, mulai dari pemilihan benih, penanaman, pemeliharaan sampai pemanenan didampingi oleh sektor pertanian. Setiap keluarga mempelajari dan menerapkan asuhan mandiri pemanfaatan TOGA dan Akupresur untuk memelihara dan meningkatkan kesehatan, mencegah dan mengatasi gangguan kesehatan ringan dalam lingkungan keluarga. Setiap keluarga berbagi pengetahuan dan keterampilan kepada keluarga lain dalam kelompok dan setiap anggota kelompok yang sudah dapat mandiri dapat mengajak 5-10 keluarga untuk bergabung dan membentuk kelompok baru. Pembinaan kelompok asuhan mandiri dilakukan oleh kader dengan didampingi oleh fasilitator Puskesmas dan mitra. Setiap bulan kader merekap catatan dari keluarga binaannya sebagai bahan evaluasi pelaksanan asuhan mandiri di kelompoknya.

Menurut laporan riset kesehatan dasar tahun 2018 proporsi pemanfaatan pelayanan kesehatan tradisional tahun 2018 jumlah anggota rumah tangga yang memanfaatkan pelayanan kesehatan tradisional 
dalam satu terakhir dengan bantuan mendatangi panti sehat/fasilitas pelayanan kesehatan tradisional/fasilitas pelayanan kesehatan atau mendatangkan penyehat tradisional/tenaga kesehatan tradisional/ terapi sebanyak 31,4\%. Sedangkan anggota rumah tangga yang melakukan dengan upaya sendiri meliputi melakukan pijat atau akupresur tanpa bantuan penyehat tradisional/tenaga kesehatan/terapis, membuat ramuan tradisional, membeli jamu gendong, jamu godok, jamu dan obat tradisional lainnya atas inisiatif sendiri, serta memanfaatkan Taman Obat Keluarga (TOGA) sebanyak 12,9\%. Proporsi jenis pelayanan kesehatan tradisional yang dimanfaatkan tahun 2018 dengan ramuan jadi $48 \%$, ramuan buatan sendiri $31,8 \%$, keterampilan manual 65,3\%, keterampilan pikir 1,9\% dan keterampilan energi 2,1\%. Proporsi Pemanfaatan TOGA tahun 2018 sebanyak 24,6\%. Provinsi DKI termasuk provinsi yang paling sedikit memanfaatkan TOGA 9,1\%, masyarakatnya lebih banyak memanfaatkan ramuan yang sudah jadi $59,6 \%$ sedangkan ramuan sendiri sangat kurang
18,7\%. Pemanfaatan pelayanan kesehatan tradisional dengan metode keterampilan manual (pijat urut, patah tulang, refleksi, akupuntur, chiropractic, kop/bekam, apiterapi, ceragem, akupresur dan lainlain) proporsi provinsi DKI termasuk besar $68,6 \% \cdot[8]$

Dengan melihat gambaran pemanfaatan TOGA dan Akupresur DKI Jakarta, maka peneliti tertarik untuk menganalisa situasi program pemanfaatan TOGA dan Akupresur di DKI Jakarta. Mengapa beberapa provinsi berhasil memanfaatkan TOGA dan Akupresur, sedangkan provinsi DKI Jakarta kurang berhasil dalam memanfaatkan TOGA.

\section{Metode}

Penelitian ini menggunakan data sekunder dari laporan Riset Kesehatan Dasar Tahun 2018. Data dianalisa secara deskriptif dengan literatur review dengan tujuan mengetahui gambaran karakteristik masyarakat dalam pemanfaatan TOGA dan Akupresur di Provinsi DKI Jakarta. 


\section{Hasil}

Tabel 1. Proporsi Pemanfaatan Pelayanan Kesehatan Tradisional menurut Provinsi, Riskesdas 2018

\begin{tabular}{|c|c|c|c|c|c|c|}
\hline No & Provinsi & $\begin{array}{c}\text { Memanfaatkan } \\
\text { Yankestrad } \\
(\%)\end{array}$ & $95 \% \mathrm{CI}$ & $\begin{array}{c}\text { Melakukan } \\
\text { Upaya Sendiri } \\
(\%)\end{array}$ & $95 \% \mathrm{CI}$ & $\begin{array}{c}\mathrm{N} \\
\text { Tertimbang }\end{array}$ \\
\hline 1 & Aceh & 15,9 & $15,1-16,7$ & 8,6 & $8,0-9,2$ & 20.244 \\
\hline 2 & Sumatera Utara & 35,2 & $34,0-36,4$ & 9,6 & $8,9-10,3$ & 55.351 \\
\hline 3 & Sumatera Barat & 31,3 & $29,9-32,8$ & 12,3 & $11,4-13,3$ & 20.663 \\
\hline 4 & Riau & 31,5 & $30,2-32,9$ & 8,7 & $8,0-9,5$ & 26.085 \\
\hline 5 & Jambi & 24,2 & $22,4-26,1$ & 10,5 & $9,3-11,8$ & 13.692 \\
\hline 6 & Sumatera Selatan & 29,5 & $27,8-31,2$ & 9,9 & $8,9-10,9$ & 32.126 \\
\hline 7 & Bengkulu & 31,2 & $29,3-33,2$ & 8,1 & $7,3-8,9$ & 7.531 \\
\hline 8 & Lampung & 42,7 & $41,3-44,1$ & 9,6 & $8,8-10,5$ & 32.148 \\
\hline 9 & Kep.Bangka Belitung & 28,4 & $26,6-30,3$ & 11,1 & $9,9-12,4$ & 5.592 \\
\hline 10 & Kepulauan Riau & 20,6 & $18,2-23,3$ & 13,6 & $10,8-16,9$ & 8.173 \\
\hline 11 & DKI Jakarta & 39,2 & $37,3-41,2$ & 11,0 & $9,7-12,4$ & 40.210 \\
\hline 12 & Jawa Barat & 23,3 & $22,5-24,2$ & 9,2 & $8,8-9,7$ & 186.809 \\
\hline 13 & Jawa Tengah & 33,0 & $32,2-33,7$ & 13,9 & $13,4-14,5$ & 132.565 \\
\hline 14 & DI Yogyakarta & 48,1 & $46,3-50,0$ & 13,4 & $12,2-14,6$ & 14.602 \\
\hline 15 & Jawa Timur & 48,3 & $47,4-49,2$ & 15,5 & $14,9-16,2$ & 151.878 \\
\hline
\end{tabular}




\begin{tabular}{ccccccc}
\hline 16 & Banten & 35,5 & $33,8-37,3$ & 14,1 & $12,7-15,6$ & 48.621 \\
\hline 17 & Bali & 19,2 & $18,1-20,5$ & 23,6 & $22,2-25,1$ & 16.481 \\
\hline 18 & Nusa Tenggara Barat & 31,5 & $29,9-33,2$ & 13,1 & $12,0-14,3$ & 19.247
\end{tabular}

\begin{tabular}{ccccccc}
\hline 19 & Nusa Tenggara Timur & 17,1 & $16,0-18,3$ & 23,0 & $21,8-24,2$ & 20.599 \\
\hline 20 & Kalimantan Barat & 19,7 & $18,3-21,1$ & 8,9 & $8,1-9,7$ & 19.190 \\
\hline 21 & Kalimantan Tengah & 28,1 & $26,1-30,1$ & 12,3 & $11,1-13,6$ & 10.189 \\
\hline 22 & & & & & & \\
\hline
\end{tabular}

\begin{tabular}{llccccc}
\hline 23 & Kalimantan Timur & 29,7 & $28,0-31,5$ & 16,6 & $15,3-18,1$ & 13.977 \\
\hline 24 & Kalimantan Utara & 17,4 & $15,2-19,8$ & 11,9 & $10,1-14,0$ & 2.733
\end{tabular}

\begin{tabular}{ccccccc}
\hline 25 & Sulawesi Utara & 24,7 & $23,3-26,1$ & 19,1 & $17,7-20,7$ & 9.542 \\
\hline 26 & Sulawesi Tengah & 22,0 & $20,4-23,7$ & 23,9 & $22,7-25,3$ & 11.548 \\
& & & & & & \\
\hline 27 & Sulawesi Selatan & 9,3 & $8,7-10,0$ & 18,8 & $18,0-19,7$ & 33.693
\end{tabular}

\begin{tabular}{ccccccc}
\hline 28 & Sulawesi Tenggara & 19,5 & $17,7-21,3$ & 12,4 & $11,2-13,7$ & 10.167 \\
\hline 29 & Gorontalo & 37,8 & $34,7-40,9$ & 11,4 & $9,8-13,3$ & 4.547
\end{tabular}

\begin{tabular}{|c|c|c|c|c|c|c|}
\hline 30 & Sulawesi Barat & 8,5 & $7,2-9,9$ & 20,5 & $18,4-22,7$ & 5.195 \\
\hline 31 & Maluku & 14,5 & $13,1-16,0$ & 19,5 & $17,9-21,2$ & 6.801 \\
\hline 32 & Maluku Utara & 24,1 & $22,5-25,8$ & 20,2 & $18,5-22,0$ & 4.723 \\
\hline 33 & Papua Barat & 15,1 & $13,3-17,0$ & 18,1 & $16,3-20,1$ & 3.588 \\
\hline 34 & Papua & 9,5 & $8,4-10,6$ & 18,3 & $16,4-20,4$ & 12.736 \\
\hline
\end{tabular}


Tabel 2. Proporsi Pemanfaatan Pelayanan Kesehatan Tradisional menurut Kotamadya DKI Jakarta, Riskesdas 2018

\begin{tabular}{|c|c|c|c|c|c|c|}
\hline No & Kotamadya DKI Jakarta & $\begin{array}{c}\text { Memanfaatkan } \\
\text { Yankestrad }\end{array}$ & $95 \% \mathrm{CI}$ & $\begin{array}{l}\text { Melakukan } \\
\text { Upaya Sendiri }\end{array}$ & $95 \% \mathrm{CI}$ & $\begin{array}{c}\mathrm{N} \\
\text { Tertimbang }\end{array}$ \\
\hline
\end{tabular}

\begin{tabular}{ccccccc}
\hline 1 & Jakarta Timur & 40,30 & $36,20-44,54$ & 12,23 & $9,41-15,74$ & 4.227 \\
\hline 2 & Jakarta Barat & 41,57 & $37,50-45,75$ & 10,79 & $7,97-14,44$ & 3,706 \\
\hline 3 & Jakarta Utara & 37,10 & $33,27-41,09$ & 11,57 & $9,45-14,08$ & 2.605 \\
\hline 4 & Jakarta Selatan & 38,42 & $34,67-42,32$ & 7,86 & $6,11-10,07$ & 3.255 \\
\hline 5 & Jakarta Pusat & 35,21 & $30,56-40,17$ & 14,09 & $10,79-18,19$ & 1.342 \\
\hline 6 & Kepulauan Seribu & 51,19 & $42,99-59,3$ & 5,96 & $4,08-8,63$ & $35^{*}$ \\
\hline & DKI Jakarta & 39,23 & $37,33-41,16$ & 10,97 & $9,69-12,40$ & 15.170 \\
\hline
\end{tabular}

Hasil Riskesdas 2018 bertujuan untuk mengetahui pemanfaatan yankestrad yaitu Anggota Rumah Tangga (ART) yang pernah memanfaatkan pelayanan kesehatan tradisional dalam satu tahun terakhir. ART pernah memanfaatkan yankestrad dengan mendatangi panti sehat/fasilitas yankestrad/fasilitas yankes atau mendatangkan penyehat tradisional/nakestrad/ terapi. Proporsi memanfaatkan Pelayanan Kesehatan Tradisional masyarakat Indonesia $31,4 \%$, tertinggi provinsi Kalimatan Selatan $54,1 \%$ dan terendah Sulawesi Barat $8,5 \%$.
ART melakukan upaya sendiri meliputi: melakukan pijat atau akupresur tanpa bantuan penyehat tradisional/nakestrad/terapis, membuat ramuan tradisional, membeli jamu gendong, jamu godok, jamu dan obat tradisional lainnya atas inisiatif sendiri, serta memanfaatkan Taman Obat Keluarga (TOGA). Proporsi melakukan upaya Kesehatan Tradisional masyarakat Indonesia 12,9\%, tertinggi provinsi Sulawesi Tengah 23,9\% dan terendah Bengkulu 8,1\%.

Masyarakat DKI Jakarta termasuk yang senang memanfaatkan pelayanan kesehatan 
tradisional, namun proporsinya kurang dalam hal asuhan mandiri atau melakukan dengan upaya sendiri. Kurangnya masyarakat dalam melakukan upaya kesehatan tradisional sendiri disebabkan kurangnya pengetahuan pada kader dan masyarakat, kurangnya antusias masyarakat dan kurangnya sosialisasi oleh petugas kesehatan. Seperti hasil penelitian Eriyana (2018) menemukan bahwa penyebab pemahaman masyarakat tentang program asuhan mandiri TOGA dan ketrampilan akupresur pada Dinas Kesehatan Kabupaten Ngawi masih rendah adalah program masih baru sehingga masih banyak kekurangan seperti minimnya pelatihan kepada masyarakat dan minimnya jumlah kader, kurangnya antusias masyarakat dan kurangnya sosialisasi. [9]

Tabel 3. Proporsi Jenis Pelayanan Kesehatan Tradisional yang Dimanfaatkan menurut Provinsi, Riskesdas 2018

\begin{tabular}{|c|c|c|c|c|c|c|c|}
\hline No & Provinsi & $\begin{array}{c}\text { Ramuan } \\
\text { Jadi }\end{array}$ & $\begin{array}{c}\text { Ramuan } \\
\text { buatan } \\
\text { sendiri }\end{array}$ & $\begin{array}{c}\text { keterampilan } \\
\text { manual }\end{array}$ & $\begin{array}{l}\text { Keterampilan } \\
\text { olah pikir }\end{array}$ & $\begin{array}{l}\text { Keterampilan } \\
\text { energi }\end{array}$ & $\begin{array}{c}\mathrm{N} \\
\text { Tertimbang }\end{array}$ \\
\hline & & $\%$ & $\%$ & $\%$ & $\%$ & $\%$ & \\
\hline 1 & Aceh & 37,0 & 60,3 & 45,2 & 2,9 & 3,6 & 4.812 \\
\hline 2 & Sumatera Utara & 48,9 & 28,4 & 72,8 & 2,0 & 2,0 & 24.033 \\
\hline 3 & Sumatera Barat & 22,8 & 55,7 & 66,0 & 1,8 & 2,4 & 8.748 \\
\hline 4 & Riau & 43,7 & 27,5 & 69,2 & 2,0 & 1,8 & 10.193 \\
\hline 5 & Jambi & 50,5 & 45,2 & 59,2 & 1,4 & 2,8 & 4.613 \\
\hline 6 & Sumatera Selatan & 34,6 & 24,4 & 79,9 & 1,7 & 1,8 & 12.257 \\
\hline 7 & Bengkulu & 29,5 & 41,8 & 67,0 & 2,1 & 2,4 & 2.871 \\
\hline 8 & Lampung & 48,2 & 37,0 & 72,7 & 1,6 & 1,4 & 16.320 \\
\hline 9 & $\begin{array}{c}\text { Kep.Bangka } \\
\text { Belitung }\end{array}$ & 43,5 & 21,6 & 73,1 & 3,3 & 3,5 & 2.141 \\
\hline 10 & Kepulauan Riau & 51,7 & 28,6 & 55,5 & 1,5 & 2,8 & 2.712 \\
\hline 11 & DKI Jakarta & 59,6 & 18,7 & 68,6 & 2,0 & 2,3 & 19.587 \\
\hline 12 & Jawa Barat & 51,9 & 28,1 & 59,3 & 2,0 & 2,4 & 58,997 \\
\hline 13 & Jawa Tengah & 55,5 & 18,5 & 64,0 & 1,9 & 1,7 & 60.323 \\
\hline 14 & DI Yogyakarta & 56,1 & 26,0 & 62,7 & 1,7 & 1,6 & 8.713 \\
\hline 15 & Jawa Timur & 51,1 & 28,7 & 78,4 & 1,9 & 2,0 & 94.054 \\
\hline
\end{tabular}




\begin{tabular}{cccccccc}
\hline 16 & Banten & 55,6 & 20,8 & 70,1 & 1,6 & 1,8 & 23.406 \\
\hline 17 & Bali & 37,5 & 49,4 & 46,6 & 2,2 & 2,3 & 6.848 \\
\hline 18 & $\begin{array}{c}\text { Nusa Tenggara } \\
\text { Barat }\end{array}$ & 33,9 & 36,5 & 57,5 & 1,5 & 3,3 & 8.328 \\
\hline 19 & $\begin{array}{c}\text { Nusa Tenggara } \\
\text { Timur }\end{array}$ & 28,9 & 69,3 & 40,6 & 1,2 & 1,9 & 8.013 \\
\hline 20 & Kalimantan Barat & 47,5 & 40,4 & 56,6 & 2,3 & 2,4 & 5.312
\end{tabular}

\begin{tabular}{cccccccc}
\hline 21 & Kalimantan Tengah & 54,7 & 30,4 & 69,4 & 2,0 & 1,9 & 3.988 \\
\hline 22 & Kalimantan Selatan & 58,4 & 17,9 & 83,3 & 1,6 & 1,8 & 9.914 \\
\hline 23 & Kalimantan Timur & 53,8 & 27,9 & 62,3 & 2,2 & 1,9 & 6.288 \\
\hline 24 & Kalimantan Utara & 49,8 & 29,5 & 50,9 & 2,6 & 1,6 & 777
\end{tabular}

\begin{tabular}{cccccccc}
\hline 25 & Sulawesi Utara & 22,4 & 70,5 & 49,4 & 1,6 & 1,5 & 4.056 \\
\hline 26 & Sulawesi Tengah & 25,5 & 60,8 & 50,5 & 1,9 & 1,7 & 5.149 \\
\hline 27 & Sulawesi Selatan & 31,2 & 70,5 & 15,6 & 1,8 & 2,7 & 9.207 \\
\hline 28 & Sulawesi Tenggara & 25,5 & 55,8 & 52,2 & 2,4 & 2,8 & 3.145
\end{tabular}

\begin{tabular}{cccccccc}
\hline 29 & Gorontalo & 25,8 & 42,6 & 76,5 & 2,3 & 2,4 & 2.172 \\
\hline 30 & Sulawesi Barat & 21,9 & 85,5 & 9,3 & 1,6 & 1,5 & 1.458 \\
\hline 31 & Maluku & 21,0 & 78,2 & 31,0 & 1,6 & 2,1 & 2.241 \\
\hline 32 & Maluku Utara & 25,2 & 75,6 & 28,0 & 1,5 & 2,1 & 2.032
\end{tabular}

\begin{tabular}{cccccccc}
\hline 33 & Papua Barat & 24,9 & 70,8 & 25,3 & 1,1 & 0,8 & 1.154 \\
\hline 34 & Papua & 18,9 & 81,7 & 17,2 & 1,7 & 3,0 & 3.432 \\
& & & & & & & \\
& & & & & & & \\
\hline
\end{tabular}

Tabel 3 merupakan hasil penelitian tentang jenis yankestrad yang dimanfaatkan dalam satu tahun terakhir meliputi:

1) Ramuan jadi, merupakan ramuan yang diperoleh dalam bentuk sediaan jadi, yang beredar di pasar dan terdaftar di Badan POM atau diberikan langsung oleh praktisi, digunakan sesuai aturan yang berlaku.

2) Ramuan buatan sendiri, merupakan ramuan 
yang dibuat secara mandiri berdasarkan pengalaman sendiri atau mengacu pada buku resmi atau informasi yang dapat dipercaya dengan bahan yang diperoleh dari taman obat keluarga atau membeli di pasar, baik dalam bentuk segar, kering atau bentuk simplisia (serbuk). Ramuan dapat digunakan untuk diminum atau pemakaian luar (misalnya balur atau oles)

3) Keterampilan manual (pijat, tusuk jarum), merupakan bagian dari pelayanan kesehatan tradisional yang dalam pelaksanaannya menggunakan keterampilan dengan ataupun tanpa alat bantu. (PP No. 103 Tahun 2014 tentang Pelayanan Kesehatan Tradisional) dan dapat dilakukan oleh Hattra ataupun nakestrad. Contoh: pijat urut dewasa/bayi, patah tulang, refleksi, akupuntur, chiropractic, kop/bekam, apiterapi, ceragem, akupresur dll.

4) Keterampilan olah pikir/hipnoterapi merupakan bagian dari pelayanan kesehatan tradisional yang dalam pelaksanaannya menggunakan teknik keterampilan olah pikir. (PP No. 103 Tahun 2014 tentang Pelayanan Kesehatan Tradisional) dan dapat dilakukan oleh Hattra ataupun nakestrad. Contoh: hipnoterapi, meditasi.

Proporsi masyarakat Indonesia dalam memanfaatkan ramuan jadi $48 \%$, ramuan buatan sendiri $31,8 \%$, keterampilan manual 65,3\%, keterampilan olah pikir $1,9 \%$ dan keterampilan energi $2,1 \%$. Provinsi terbanyak memanfaatkan ramuan jadi Kalimantan Selatan 58,4\%, sedangkan provinsi terbanyak membuat ramuan sendiri Sulawesi Barat 85,5\%. Dalam hal memanfaatkan keterampilan manual terbanyak provinsi Kalimantan Selatan 83,3\%, keterampilan olah Kepulauan Bangka Belitung 3,3\% dan keterampilan energi Aceh 3,6\%.

Masyarakat DKI Jakarta termasuk yang lebih banyak memanfaatkan ramuan jadi $59,6 \%$ dibandingkan membuat ramuan sendiri $18,7 \%$, sedangkan untuk keterampilan manual termasuk banyak $68,6 \%$.

Tabel 4. Proporsi Pemanfaatan TOGA menurut Provinsi, Riskesdas 2018

\begin{tabular}{ccccc}
\hline No & Provinsi & Pernah Memanfaatkan TOGA & $\begin{array}{c}\text { N } \\
\text { Tertimbang }\end{array}$ \\
\hline & & $\%$ & $95 \% \mathrm{Cl}$ & \\
\hline 1 & Aceh & 36,3 & $34,3-38,5$ & 4.812 \\
\hline 2 & Sumatera & 22,2 & $20,9-23,5$ & 24.033
\end{tabular}




\begin{tabular}{|c|c|c|c|c|}
\hline & Utara & & & \\
\hline 3 & $\begin{array}{c}\text { Sumatera } \\
\text { Barat }\end{array}$ & 50,4 & $48,5-52,3$ & 8.748 \\
\hline 4 & Riau & 26,7 & $25,1-28,5$ & 10.193 \\
\hline 5 & Jambi & 39,4 & $36,3-42,5$ & 4.613 \\
\hline 6 & $\begin{array}{l}\text { Sumatera } \\
\text { Selatan }\end{array}$ & 24,1 & $22,1-26,3$ & 12.257 \\
\hline 7 & Bengkulu & 41,9 & $38,8-45,1$ & 2.871 \\
\hline 8 & Lampung & 31,6 & $29,7-33,16$ & 16.320 \\
\hline 9 & $\begin{array}{c}\text { Kep.Bangka } \\
\text { Belitung }\end{array}$ & 18,1 & $16,2-20,1$ & 2.141 \\
\hline 10 & $\begin{array}{l}\text { Kepulauan } \\
\text { Riau }\end{array}$ & 22,0 & $18,7-25,6$ & 2.712 \\
\hline 11 & DKI Jakarta & 9,1 & $8,1-10,3$ & 19.587 \\
\hline 12 & Jawa Barat & 20,3 & $19,3-21,3$ & 58,997 \\
\hline 13 & Jawa Tengah & 16,9 & $16,2-17,6$ & 60.323 \\
\hline 14 & $\begin{array}{c}\text { DI } \\
\text { Yogyakarta }\end{array}$ & 25,1 & $23,3-27,0$ & 8.713 \\
\hline 15 & Jawa Timur & 21,8 & $21,0-22,5$ & 94.054 \\
\hline 16 & Banten & 17,4 & $16,0-18,9$ & 23.406 \\
\hline 17 & Bali & 40,3 & $38,2-42,5$ & 6.848 \\
\hline 18 & $\begin{array}{c}\text { Nusa } \\
\text { Tenggara } \\
\text { Barat }\end{array}$ & 19,6 & $17,8-21,6$ & 8.328 \\
\hline 19 & $\begin{array}{c}\text { Nusa } \\
\text { Tenggara } \\
\text { Timur }\end{array}$ & 55,1 & $52,9-57,3$ & 8.013 \\
\hline 20 & $\begin{array}{l}\text { Kalimantan } \\
\text { Barat }\end{array}$ & 34,7 & $32,6-36,9$ & 5.312 \\
\hline 21 & $\begin{array}{l}\text { Kalimantan } \\
\text { Tengah }\end{array}$ & 26,7 & $24,7-28,9$ & 3.988 \\
\hline 22 & $\begin{array}{l}\text { Kalimantan } \\
\text { Selatan }\end{array}$ & 17,7 & $16,5-19,0$ & 9.914 \\
\hline 23 & $\begin{array}{l}\text { Kalimantan } \\
\text { Timur }\end{array}$ & 24,2 & $22,3-26,3$ & 6.288 \\
\hline
\end{tabular}




\begin{tabular}{ccccc}
\hline 24 & $\begin{array}{c}\text { Kalimantan } \\
\text { Utara }\end{array}$ & 23,5 & $20,7-26,6$ & 777 \\
\hline 25 & $\begin{array}{c}\text { Sulawesi } \\
\text { Utara }\end{array}$ & 55,6 & $53,5-57,7$ & 4.056 \\
\hline 26 & $\begin{array}{c}\text { Sulawesi } \\
\text { Tengah }\end{array}$ & 44,7 & $42,4-47,1$ & 5.149 \\
\hline 27 & $\begin{array}{c}\text { Sulawesi } \\
\text { Selatan }\end{array}$ & 49,4 & $47,6-51,2$ & 9.207 \\
\hline 28 & $\begin{array}{c}\text { Sulawesi } \\
\text { Tenggara }\end{array}$ & 31,2 & $28,5-34,0$ & 3.145 \\
& & & \\
\hline
\end{tabular}

\begin{tabular}{|c|c|c|c|c|}
\hline 29 & Gorontalo & 38,1 & $35,5-40,7$ & 2.172 \\
\hline 30 & $\begin{array}{c}\text { Sulawesi } \\
\text { Barat }\end{array}$ & 54,4 & $50,2-58,5$ & 1.458 \\
\hline 31 & Maluku & 39,0 & $35,6-42,5$ & 2.241 \\
\hline 32 & $\begin{array}{l}\text { Maluku } \\
\text { Utara }\end{array}$ & 37,8 & $34,9-40,7$ & 2.032 \\
\hline 33 & Papua Barat & 28,7 & $25,3-32,4$ & 1.154 \\
\hline 34 & Papua & 44,1 & $40,1-48,3$ & 3.432 \\
\hline & INDONESIA & 24,6 & $\begin{array}{c}24,2 \\
- \\
24,9\end{array}$ & 437.291 \\
\hline
\end{tabular}

Tabel 4 menjelaskan proporsi pemanfaatan TOGA yaitu ART pernah memanfaatkan TOGA milik keluarga atau lingkungan sekitar dalam 1 tahun terakhir pada ART yang pernah memanfaatkan pelayanan kesehatan tradisional dalam satu tahun terakhir. TOGA atau taman obat keluarga adalah sekumpulan tanaman berkhasiat obat untuk kesehatan keluarga. TOGA pada hakekatnya adalah sebidang tanah, baik di halaman rumah, kebun ataupun ladang yang digunakan untuk membudidayakan tanaman yang berkhasiat sebagai obat, termasuk TOGA milik RT/RW atau tetangga. Tidak termasuk pemanfaatan TOGA jika mengambil tumbuhan liar di hutan atau di sembarang tempat.

Masyarakat Provinsi Sulawesi Utara paling memanfaatkan TOGA yaitu sebesar 55,6\%. Menurut Kinho (2011) masyarakat tradisional di Sulawesi Utara yang bermukim di sekitar kawasan hutan telah banyak memanfaatkan sumberdaya hutan khususnya 
tumbuhan untuk memenuhi kebutuhan hidupnya seperti keperluan pangan, bahan konstruksi rumah, dan lainnya begitu pula obat-obatan tradisional, kayu bakar dan sebagainya. Pengetahuan mengenai pengobatan secara tradisional, terutama yang bahan bakunya berasal dari alam telah dikenal sejak zaman

Tabel 5. Proporsi Pemanfaatan Pelayanan Kesehatan Tradisional Menurut Karakteristik, Provinsi DKI Jakarta, Riskesdas 2018

\begin{tabular}{|c|c|c|c|c|c|c|}
\hline No & Karakteristik & $\begin{array}{c}\text { Memanfaatkan } \\
\text { Yankestrad } \\
(\%)\end{array}$ & $95 \% \mathrm{CI}$ & $\begin{array}{c}\text { Melakukan } \\
\text { Upaya Sendiri }\end{array}$ & $95 \% \mathrm{CI}$ & $\begin{array}{c}\mathrm{N} \\
\text { Tertimbang }\end{array}$ \\
\hline
\end{tabular}

purba di Tanah Minahasa. Pengetahuan ini biasanya diturunkan dari generasi ke generasi. ${ }^{10}$ Dalam hal pemanfaatan TOGA di pekarangan rumah, masyarakat DKI Jakarta termasuk yang kurang memanfaatkan TOGA hanya $9,1 \%$.

\begin{tabular}{|c|c|c|c|c|c|c|}
\hline \multirow[t]{14}{*}{1} & Umur (tahun) & & & & & \\
\hline & $<1$ & 40,33 & $36,68-44,10$ & 7,35 & $5,68-9,47$ & 1.320 \\
\hline & $1-4$ & 30,37 & $27,86-33,01$ & 10,98 & \multirow{2}{*}{$\begin{array}{l}9,12- \\
13,16\end{array}$} & 2.459 \\
\hline & $5-14$ & 31,39 & $28,66-34,26$ & 10,25 & & 2.169 \\
\hline & $15-24$ & 40,58 & $37,70-43,53$ & 11,67 & $\begin{array}{l}8,55- \\
12,26\end{array}$ & 2.900 \\
\hline & $25-34$ & 45,64 & $42,78-48,52$ & 11,59 & \multirow{2}{*}{$\begin{array}{l}9,48- \\
14,28\end{array}$} & 2.628 \\
\hline & $35-44$ & 44,24 & $41,21-47,31$ & 12,17 & & 1.882 \\
\hline & $45-54$ & 44,11 & $40,60-47,67$ & 11,65 & $\begin{array}{c}10,00- \\
13,39\end{array}$ & 1.160 \\
\hline & $55-64$ & 42,82 & $37,95-47,83$ & 10,36 & \multirow{2}{*}{$\begin{array}{c}10,24- \\
14,40\end{array}$} & 497 \\
\hline & $65-74$ & 37,28 & $29,39-45,90$ & 10,97 & & 154 \\
\hline & \multirow[t]{4}{*}{$>75$} & \multirow[t]{4}{*}{39,23} & \multirow[t]{4}{*}{$37,33-41,16$} & 10,97 & $\begin{array}{l}9,37- \\
14,39\end{array}$ & \multirow[t]{4}{*}{15.170} \\
\hline & & & & & $\begin{array}{l}7,57- \\
14,03\end{array}$ & \\
\hline & & & & & $\begin{array}{c}7,30- \\
16,16\end{array}$ & \\
\hline & & & & & $\begin{array}{l}9,69- \\
12,40\end{array}$ & \\
\hline \multirow[t]{2}{*}{2} & Jenis Kelamin & & & & & \\
\hline & Perempuan & 41,23 & $39,08-43,42$ & 11,54 & $10,14-$ & 7.524 \\
\hline
\end{tabular}




\begin{tabular}{|c|c|c|c|c|c|c|}
\hline & \multirow[t]{2}{*}{ Laki-laki } & \multirow[t]{2}{*}{37,24} & \multirow[t]{2}{*}{$35,20-39,33$} & \multirow[t]{2}{*}{10,41} & 13,10 & \multirow[t]{2}{*}{7.608} \\
\hline & & & & & $\begin{array}{l}9,04- \\
11,97\end{array}$ & \\
\hline \multirow[t]{11}{*}{3} & Pendidikan & & & & & \\
\hline & Tidak/belum & 35,66 & $31,59-39,94$ & 13,61 & \multirow{2}{*}{$\begin{array}{l}10,86- \\
16,92\end{array}$} & 849 \\
\hline & $\begin{array}{l}\text { pernah } \\
\text { sekolah }\end{array}$ & 34,65 & $31,68-37,74$ & 12,13 & & 1.916 \\
\hline & Tidak tamat & 39,22 & $36,20-42,32$ & 11,98 & $\begin{array}{l}9,98- \\
14,67\end{array}$ & 1.926 \\
\hline & $\mathrm{SD} / \mathrm{MI}$ & 38,17 & $35,40-41,02$ & 12,02 & \multirow{2}{*}{$\begin{array}{l}9,91- \\
14,41\end{array}$} & 2.234 \\
\hline & Tamat SD/MI & 40,87 & $38,60-43,18$ & 10,80 & & 5.051 \\
\hline & $\begin{array}{l}\text { Tamat } \\
\text { SLTP/MTS }\end{array}$ & \multirow[t]{5}{*}{43,05} & \multirow[t]{5}{*}{$39,33-46,85$} & \multirow[t]{5}{*}{9,65} & $\begin{array}{l}10,06- \\
14,31\end{array}$ & \multirow[t]{5}{*}{1.694} \\
\hline & Tamat & & & & $9,25-$ & \\
\hline & SLTA/MA & & & & 12,57 & \\
\hline & Tamat & & & & $7,80-$ & \\
\hline & D1/D2/D3/PT & & & & 11,89 & \\
\hline \multirow[t]{13}{*}{4} & Pekerjaan & & & & & \\
\hline & Tidak bekerja & 42,63 & $40,13-45,16$ & 11,73 & \multirow{2}{*}{$\begin{array}{c}10,09- \\
13,59\end{array}$} & 3.851 \\
\hline & \multirow{4}{*}{$\begin{array}{l}\text { Sekolah } \\
\text { PNS/TNI/Polri } \\
\text { /BUMN/BUM } \\
\text { D Pegawai } \\
\text { swasta }\end{array}$} & 29,58 & $26,79-32,54$ & 9,95 & & 1.747 \\
\hline & & 46,59 & $39,12-54,22$ & 11,29 & $\begin{array}{l}8,20- \\
12,03\end{array}$ & 284 \\
\hline & & 38,23 & $35,53-41,01$ & 9,24 & \multirow{2}{*}{$\begin{array}{l}6,63- \\
18,59\end{array}$} & 2.620 \\
\hline & & 43,13 & $39,75-46,57$ & 13,04 & & 1.830 \\
\hline & \multirow{2}{*}{$\begin{array}{l}\text { Petani/buruh } \\
\text { tani }\end{array}$} & 39,72 & $25,81-55,52$ & 10,76 & $\begin{array}{l}7,63- \\
11,15\end{array}$ & 75 \\
\hline & & 29,56 & $12,42-55,39$ & 11,76 & \multirow{2}{*}{$\begin{array}{l}10,89- \\
15,53\end{array}$} & $25^{*}$ \\
\hline & Nelayan & 39,65 & $36,14-43,26$ & 14,87 & & 1.366 \\
\hline & \multirow{4}{*}{$\begin{array}{l}\text { Buruh/sopir/pe } \\
\text { mbantu ruta } \\
\text { Lainnya }\end{array}$} & 45,53 & $40,93-50,21$ & 8,84 & $\begin{array}{l}4,63- \\
23,06\end{array}$ & 801 \\
\hline & & & & & $\begin{array}{l}2,64- \\
39,55\end{array}$ & \\
\hline & & & & & $\begin{array}{l}12,16- \\
18,05\end{array}$ & \\
\hline & & & & & $\begin{array}{l}6,44- \\
12,03\end{array}$ & \\
\hline \multirow[t]{4}{*}{5} & Tempat & & & & \multirow{3}{*}{$\begin{array}{l}9,69- \\
12,40\end{array}$} & \\
\hline & Tinggal & 39,23 & $37,33-41,16$ & 10,97 & & 15.170 \\
\hline & Perkotaan & - & - & - & & _- \\
\hline & Pedesaan & & & & - & \\
\hline
\end{tabular}


Tabel 5 menjelaskan karakteristik pemanfaatan pelayanan kesehatan tradisional pada masyarakat

DKI Jakarta. Menurut karakteristik masyarakat DKI Jakarta terbanyak memanfaatkan pelayanan kesehatan tradisional adalah umur 25-34 tahun $(45,64 \%)$, gender perempuan $(41,23 \%)$, Pendidikan perguruan tinggi $(43,05 \%)$ dan pegawai pemerintahan $(46,59 \%)$.

Tabel 6. Proporsi Jenis Pelayanan Kesehatan Tradisional yang Dimanfaatkan menurut Kotamadya DKI Jakarta, Riskesdas 2018

\begin{tabular}{|c|c|c|c|c|c|c|c|}
\hline No & DKI Jakarta & $\begin{array}{c}\text { Ramuan } \\
\text { Jadi }\end{array}$ & $\begin{array}{c}\text { Ramuan } \\
\text { buatan } \\
\text { sendiri }\end{array}$ & $\begin{array}{c}\text { keterampilan } \\
\text { manual }\end{array}$ & $\begin{array}{c}\text { Keterampilan } \\
\text { olah pikir }\end{array}$ & $\begin{array}{c}\text { Keterampilan } \\
\text { energi }\end{array}$ & $\begin{array}{c}\mathrm{N} \\
\text { Tertimbang }\end{array}$ \\
\hline & & $\%$ & $\%$ & $\%$ & $\%$ & $\%$ & \\
\hline 1 & Kepulauan Seribu & 66,06 & 9,28 & 70,91 & 1,28 & 1,66 & $20 *$ \\
\hline 2 & $\begin{array}{l}\text { Kota Jakarta } \\
\text { Selatan }\end{array}$ & 52,3 & 14,97 & 71,90 & 2,23 & 2,76 & 1.510 \\
\hline 3 & Kota Jakarta Timur & 60,03 & 25,19 & 65,78 & 1,82 & 2,03 & 2.226 \\
\hline 4 & Kota Jakarta Pusat & 65,43 & 12,79 & 61,16 & 3,59 & 2,13 & 663 \\
\hline 5 & Kota Jakarta Barat & 60,33 & 16,94 & 73,84 & 1,72 & 2,40 & 1.945 \\
\hline 6 & KotaJakarta Utara & 63,01 & 17,49 & 65,23 & 1,85 & 2,15 & 1.271 \\
\hline 7 & Prov. DKI Jakarta & 59,60 & 18,67 & 68,56 & 2,03 & 2,29 & 7.635 \\
\hline
\end{tabular}

Untuk wilayah DKI Jakarta terbanyak memanfaatkan ramuan jadi adalah Kepulauan Seribu $66,06 \%$, sedangkan tamuan buatan sendiri Jakarta
Timur 25,19\%, keterampilan manual Jakarta Barat 73,8\%, keterampilan olah pikir Jakarta Pusat 3,59\% dan keterampilan energi Jakarta Selatan 2,76\%

Tabel 7. Proporsi Jenis Pelayanan Kesehatan Tradisional yang Dimanfaatkan menurut Karakteristik Kotamadya DKI Jakarta, Riskesdas 2018

\begin{tabular}{ccccccc}
\hline No Kotamadya DKI Jakarta & $\begin{array}{c}\text { Ramuan } \\
\text { Jadi }\end{array}$ & $\begin{array}{c}\text { Ramuan } \\
\text { buatan } \\
\text { sendiri }\end{array}$ & $\begin{array}{c}\text { keterampilan } \\
\text { manual }\end{array}$ & $\begin{array}{c}\text { Keterampilan } \\
\text { olah pikir }\end{array}$ & $\begin{array}{c}\text { Keterampi } \\
\text { lan energi }\end{array}$ & $\begin{array}{c}\text { N } \\
\text { Tertimbang }\end{array}$ \\
\hline & $\%$ & $\%$ & $\%$ & $\%$ & $\%$ \\
\hline 1 & Umur (tahun) & & & & & \\
& 32,91 & 7,49 & 84,81 & 0,90 & 1,00 & 631
\end{tabular}




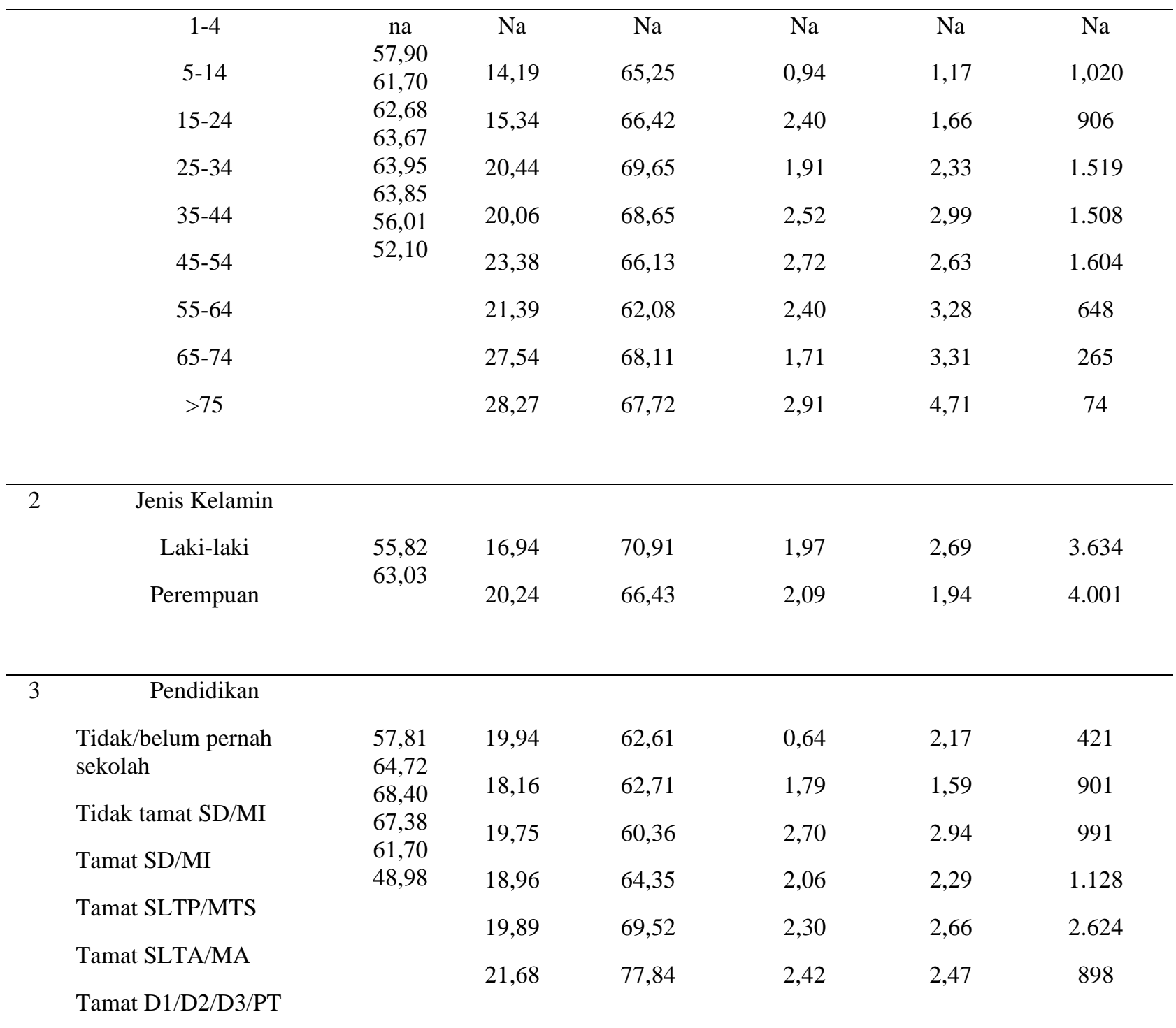

\begin{tabular}{lllllll}
\hline \multicolumn{1}{c}{ Pekerjaan } & & & & & & \\
Tidak bekerja & 64,32 & 22,48 & 63,67 & 2,23 & 2,38 & 2.111 \\
Sekolah & 59,45 & 15,30 & 66,82 & 1,55 & 1,23 & 697 \\
$\begin{array}{l}\text { PNS/TNI/Polri/BUMN/B } \\
\text { UMD }\end{array}$ & 50,76 & 24,26 & 78,41 & 3,20 & 2,83 & 166 \\
Pegawai swasta & 59,09 & 18,33 & 73,01 & 2,51 & 2,72 & 1.254 \\
Wiraswasta & 63,35 & 21,44 & 66,70 & 2,35 & 3,24 & 1.037 \\
Petani/buruh tani & 66,87 & 8,25 & 57,06 & 3,52 & 0,0 & $38^{*}$ \\
Nelayan & 72,29 & 40,07 & 68,55 & 0,33 & 0,48 & $10^{*}$ \\
Buruh/sopir/pembantu & 65,82 & 18,21 & 64,14 & 2,13 & 2,54 & 751 \\
ruta & 62,14 & 20,79 & 73,65 & 2,20 & 2,94 & 439 \\
Lainnya & & & & & &
\end{tabular}




\begin{tabular}{ccccccc}
\hline 5 & Tempat Tinggal & & & & & \\
Perkotaan & 59,60 & 18,67 & 68,56 & 2,03 & 2,29 & 7.635 \\
Pedesaan & & & & & \\
\hline
\end{tabular}

Menurut karakteristik masyarakat DKI membuat ramuan sendiri usia $>75$ tahun $28,27 \%$. Jakarta, yang terbanyak memanfaatkan ramuan jadi Dalam hal memanfaatkan keterampilan manual usia 45-54 tahun sebesar 63,95\%, sedangkan paling banyak usia $<1$ tahun sebesar $84,1 \%$.

Tabel 8. Proporsi Pemanfaatan TOGA menurut Kotamadya DKI JAkarta, Riskesdas 2018

\begin{tabular}{ccccc}
\hline No & DKI Jakarta & Pernah Memanfaatkan TOGA & $\begin{array}{c}\text { N } \\
\text { Tertimbang }\end{array}$ \\
\hline & & & & \\
\hline 1 & Kepulauan Seribu & $\mathbf{1 2 , 0 0}$ & $8,15-$ & $20 *$ \\
& & & 17,33 & \\
\hline 2 & Kota Jakarta & 11,06 & 1.510 \\
& Selatan & & $8,85-$ & \\
\hline 3 & Kota Jakarta & & 13,75 & \\
& Timur & 8,93 & $6,80-$ & 2.226 \\
\hline 4 & Kota Jakarta Pusat & 5,31 & 11,64 & \\
\hline 5 & Kota Jakarta Barat & 7,99 & $3,50-7,97$ & 663 \\
\hline 6 & Kota Jakarta Utara & 10,86 & $6,26-$ & 1.945 \\
& & & 10,15 & \\
\hline 7 & DKI Jakarta & 9,13 & $8,44-$ & 1.271 \\
\hline
\end{tabular}

Dalam hal memanfaatkan TOGA di wilayah DKI Jakarta adalah Kepulauan Seribu sebesar 12\%. 
Tabel 9. Proporsi Pemanfaatan TOGA menurut Karakteristik DKI Jakarta, Riskesdas 2018

\begin{tabular}{|c|c|c|c|c|}
\hline \multirow[t]{2}{*}{ No } & \multirow[t]{2}{*}{ Provinsi } & \multicolumn{2}{|c|}{$\begin{array}{c}\text { Pernah Memanfaatkan } \\
\text { TOGA }\end{array}$} & \multirow[t]{2}{*}{$\begin{array}{c}\mathrm{N} \\
\text { Tertimbang }\end{array}$} \\
\hline & & $\%$ & $\begin{array}{l}95 \% \\
\mathrm{Cl}\end{array}$ & \\
\hline \multirow[t]{14}{*}{1} & Umur & & & \\
\hline & $<1$ th & 5,78 & $3,79-$ & 631 \\
\hline & $1-4$ th & $\mathrm{Na}$ & 8,74 & $\mathrm{Na}$ \\
\hline & $5-14$ th & 4,90 & $\mathrm{Na}$ & 1.020 \\
\hline & $15-24$ th & 6,84 & $\begin{array}{c}3,56- \\
6,70\end{array}$ & 906 \\
\hline & $25-34$ th & 7,92 & $4,95-$ & 1.519 \\
\hline & $35-44$ th & 9,77 & 9,37 & 1.508 \\
\hline & $45-54$ th & 12,86 & $\begin{array}{c}6,26- \\
9,97\end{array}$ & 1.604 \\
\hline & $55-64$ th & 13,78 & 801 & 648 \\
\hline & $65-74$ th & 17,45 & 11,87 & 265 \\
\hline & $>=75$ th & 11,54 & $\begin{array}{c}10,61- \\
15,51\end{array}$ & 74 \\
\hline & & & $\begin{array}{c}10,88- \\
17,30\end{array}$ & \\
\hline & & & $\begin{array}{l}12,86- \\
23,24\end{array}$ & \\
\hline & & & $\begin{array}{l}6,70- \\
19,18\end{array}$ & \\
\hline
\end{tabular}

\begin{tabular}{cccc}
\hline 2. Jenis Kelamin & & & \\
Laki-laki & 8,40 & $7,25-$ & 3.634 \\
Perempuan & 9,79 & 9,71 & 4.001 \\
& & $8,56-$ & \\
& & 11,18 & \\
\hline $3 \quad$ Pendidikan & & & \\
& & & 421 \\
Tidak/belum pernah sekolah & 7,19 & 10,80 & 901 \\
Tidak tamat SD/MI & 8,27 & $5,99-$ & 991 \\
Tamat SD/MI & 8,35 & 11,32 & 1.128 \\
Tamat SLTP/MTS & 7,4 & $6,39-$ & 2.624 \\
Tamat SLTA/MA & 10,03 & 10,85 & 898 \\
Tamat D1/D2/D3/PT & 13,97 & $5,74-$ & \\
& & &
\end{tabular}




\begin{tabular}{|c|c|c|c|c|}
\hline & & \multicolumn{3}{|c|}{9,48} \\
\hline & & \multicolumn{3}{|c|}{$\begin{array}{l}8,43- \\
11,90\end{array}$} \\
\hline & & & \multicolumn{2}{|l|}{$\begin{array}{c}11,28- \\
17,17\end{array}$} \\
\hline \multirow[t]{13}{*}{4} & Pekerjaan & & & \\
\hline & Tidak bekerja & 12,23 & \multirow{2}{*}{$\begin{array}{c}10,49- \\
14,20\end{array}$} & 2.111 \\
\hline & Sekolah & 5,44 & & 697 \\
\hline & PNS/TNI/Polri/BUMN/BUMD & 13,65 & $\begin{array}{l}3,75- \\
7,84\end{array}$ & 166 \\
\hline & Pegawai swasta & 8,98 & \multirow{2}{*}{$\begin{array}{l}8,49- \\
21,22\end{array}$} & 1.254 \\
\hline & Wiraswasta & 9,74 & & 1.037 \\
\hline & Petani/buruh tani & 5,39 & $\begin{array}{l}7,03- \\
11,40\end{array}$ & $38 *$ \\
\hline & Nelayan & 4,45 & \multirow{2}{*}{$\begin{array}{c}7,65- \\
12,32\end{array}$} & $10 *$ \\
\hline & Buruh/sopir/pembantu ruta & 7,54 & & 751 \\
\hline & \multirow[t]{4}{*}{ Lainnya } & 11,30 & $\begin{array}{l}1,30- \\
19,71\end{array}$ & 439 \\
\hline & & & $\begin{array}{l}1,42- \\
13,13\end{array}$ & \\
\hline & & & $\begin{array}{c}5,67- \\
9,95\end{array}$ & \\
\hline & & & $\begin{array}{l}8,17- \\
15,42\end{array}$ & \\
\hline \multirow[t]{3}{*}{5} & Tempat Tinggal & & \multirow{3}{*}{$\begin{array}{l}8.09- \\
10,29\end{array}$} & \multirow{3}{*}{$\begin{array}{l}7.635 \\
-\end{array}$} \\
\hline & Perkotaan & 9,13 & & \\
\hline & Pedesaan & - & & \\
\hline
\end{tabular}


Menurut karakteristik masyarakat DKI Jakarta, usia terbanyak memanfaatkan TOGA adalah usia 65-74 tahun sebesar $17,45 \%$ dan gender perempuan lebih banyak memanfaatkan TOGA.

Diskusi

Menurut Hill \& Jones (2010) strategi memiliki dampak besar pada kinerja manajer terhadap para pesaingnya. Strategi adalah serangkaian tindakan terkait yang diambil manajer untuk meningkatkan kinerja perusahaan mereka. Bagi sebagian besar, jika tidak semua organisasi, mencapai kinerja yang tinggi terhadap pesaing tantangan utama. Jika strategi organisasi menghasilkan kinerja yang unggul, itu adalah dikatakan memiliki keunggulan kompetitif. Manajer mesti mengidentifikasi dan menjelaskan strategi yang dapat ditempuh untuk mencapai kinerja yang unggul dan memberi keunggulan kompetitif bagi perusahaannya.[11]

Untuk mendorong program pemanfaatan TOGA dan Akupresur diseluruh Indonesia, maka Kementerian Kesehatan telah menyelenggarakan pelatihan bagi tenaga Puskesmas sebagai fasilitator pemanfaatan TOGA dan Akupresur di wilayah kerjanya. Termasuk provinsi DKI Jakarta. Selain melakukan pelatihan pemanfaatan TOGA dan Akupresur bagi tenaga Puskesmas, Kementerian Kesehatan juga melakukan kegiatan penilaian pemanfaatan TOGA dan Akupresur tingkat Nasional tiap tahun sejak tahun 2015. Kegiatan penilaian ini merupakan strategi untuk meningkatkan perilaku masyarakat dalam memanfaatkan TOGA di halaman rumahnya masing-masing dan memanfaatkan akupresur secara mandiri untuk memelihara kesehatan tubuhnya masing-masing.

Menurut Naibaho (2014) perlombaan desa berpengaruh positif dan signifikan terhadap prakarsa masyarakat dan peran serta masyarakat dalam membangun desa di Kecamatan Teluk Mengkudu. Dengan kata lain bila pelaksanaan perlombaan desa semakin ditingkatkan, maka prakarsa masyarakat dan peran serta masyarakat dalam membangun desa di Kecamatan Teluk Mengkudu juga akan semakin meningkat. Perlombaan desa sebagai sarana untuk mendidik masyarakat ternyata dapat merangsang (memotivasi) masyarakat di Kecamatan Teluk Mengkudu untuk ikut berpartisipasi dalam membangun desanya .[12]

$$
\text { Hasil penelitian Dwisatyadini }
$$

permasalahan pemanfaatan TOGA di daerah perkotaan adalah kurangnya lahan, namun dapat terlaksana melalui penerapan program pemerintah (Smart Government) yang mensosialisasikan pemanfaatan lahan pekarangan sebagai media untuk budidaya tanaman obat, sehingga masyarakat diperkotaan dapat lebih merasakan manfaat dari tanaman obat (Smart Living). Terlihat pada keberhasilan sosialisasi pemerintah yang dilakukan oleh Puskesmas Kecamatan Pasar Rebo dengan pergerak PKK RT 011, RW 003 Kalisari, Pasar Rebo, Jakarta Timur, yang mana telah 
berhasil mensosialisasikan pemanfaatan tanaman obat keluarga (TOGA), sehingga masyarakat yang tinggal pada RT 011, RW 003, Kalisari, Pasar Rebo dapat memanfaatkan keunggulan tanaman obat untuk mengobati penyakit degeneratif dalam keluarganya .[13]

Nurdiwaty (2017) juga menjelaskan bahwa Desa Burengan merupakan salah satu desa di Kecamatan Pesantren Kota Kediri yang berada di pusat kota Kediri. Umumnya masyarakat di wilayah tersebut tidak memiliki lahan pekarangan yang cukup luas, sehingga pemanfaatan dan pengelolaan lingkungan dapat dioptimalkan dengan penanaman TOGA dengan media polybag. Berdasarkan observasi di lapangan diketahui bahwa beberapa ibu rumah tangga telah menanam TOGA, namun demikian jumlah TOGA yang ditanam jumlahnya terbatas. Tanaman TOGA bisa ditanam meskipun dengan lahan yang sangat terbatas ternyata memberikan manfaat bagi ekonomi keluarga, baik sebagai obat yang bisa dijadikan alternatiF maupun sebagai salah satu sumber penghasilan keluarga. Ibu-ibu mampu menambah pendapatan keluarga dengan menanam tanaman TOGA sehingga bisa meningkatkan ekonomi keluarga .[14]

$$
\text { Selain permasalahan lahan terbatas, }
$$
pemberdayaan masyarakat atau peran serta masyarakat dalam hal pendanaan juga terbatas. Hal ini sesuai penelitian Laksmiarti dkk (2013) yang menunjukkan bahwa sebagian besar anggaran Kabupaten Kepulauan Aru digunakan untuk kegiatan tidak langsung yaitu
$54,67 \%$ dan kegiatan langsung sebesar 45,33\%. Hasil pemetaan pembiayaan juga menunjukkan bahwa program kesehatan masyarakat menyerap $11,25 \%$ dari total anggaran, 18,36\% untuk program upaya kesehatan individual dan sisanya $70,39 \%$ untuk program penunjang.[15]

Hasil penelitian yang dilakukan Fadmawati (2017) menunjukkan jumlah sarana kesehatan tersebut tidak memiliki pengaruh signifikan terhadap alokasi belanja desa bidang kesehatan dikarenakan sarana kesehatan hanya sekali bangun saja jadi untuk kedepannya sekedar pemeliharaan, sedangkan untuk biaya pemeliharannya kecil sehingga tidak berpengaruh dan pengalokasiannya tidak diprioritaskan terhadap jumlah sarana kesehatan yang ada di desa-desa Kabupaten Wonogiri.Sarana kesehatan merupakan salah satu sarana yang vital. Sarana kesehatan yang ada dalam desa seperti Upaya Kesehatan Bersumber Daya Masyarakat (UKBM) diantaranya Posyandu, Poskesdes, dan Polindes. Banyaknya jumlah sarana kesehatan di suatu wilayah secara tidak langsung menunjukkan tingkat kesehatan masyarakat. Untuk mencapai pembangunan yang berkualitas tentunya diperlukan sumber daya yang juga berkualitas, sehingga perlu diupayakan kegiatan dan strategi pemerataan kesehatan dengan mendayagunakan segenap potensi yang ada.[17]

Menurut Yuliani (2016) untuk mendorong masyarakat memanfaatkan pekarangan halaman rumahnya dibutuhkan kader. Kader merupakan penghubung 
antara kelompok asuhan mandiri dengan petugas Puskesmas penanggungjawab pelayanan kesehatan tradisional. Permasalahan yang muncul dalam pelaksanaan program pemberdayaan dan peran serta masyarakat dalam bidang kesehatan adalah tingginya drop out kader. Persentase kader aktif secara nasional adalah 69,2\% sehingga angka drop out kader 30,8\%. Kader drop out adalah mekanisme yang alamiah karena pekerjaan yang didasari sukarela tentu saja secara kesisteman tidak mempunya ikatan yang kuat. Hubungan kerja berhubungan kuat dengan kinerja kader Posyandu, apabila terjadi kekompakan antara sesama kader dalam mengerjakan tugas-tugas dalam kegiatan Posyandu, terjalin hubungan baik pegawai Puskesmas dan aparat desa dengan seorang kader, serta dengan pembuatan catatan kegiatan Posyandu yang dilakukan secara rutin menyebabkan hubungan antara sesama kader semakin baik. Prosedur kerja dengan kinerja kader Posyandu di Kecamatan Bulo Kabupaten Polewali Mandar juga mempunyai hubungan signifikan.Hal ini disebabkan prosedur kerja yang telah ditetapkan sudah diikuti oleh sebagian kader seperti pelaksanaan pelayanan Posyandu disesuaikan dengan prosedur pelayanan yaitu mulai dari tahap pendaftaran hingga tahap pelayanan, prosedur pelayanan Posyandu yang sesuai dengan tupoksi seorang kader, kader dalam memberikan pelayanan Posyandu tetap memperhatikan kondisi kesehatan ibu dan anak yang sesuai dengan prosedur kerja serta kader tetap menyesuaikan perkembangan kondisi kesehatan ibu dan anak ketika melaksanakan pelayanan Posyandu.

TOGA dan Akupresur sebenarnya bukanlah program yang baru, namun program pemanfaatan TOGA dan Akupresur perlu rutin disosialisasikan ke masyarakat sehingga masyarakat menyadari pemanfaatan TOGA dan Akupresur bagi kesehatan dirinya, keluarga dan lingkungan sekitarnya. Seperti hasil penelitian yang dilakukan Eriyana dkk (2018) penyebab pemahaman masyarakat tentang program asuhan mandiri Taman Obat Kelurga (TOGA) dan ketrampilan akupresur pada Dinas Kesehatan Kabupaten Ngawi masih rendah serta belum berjalan optimal kurangnya antusias masyarakat dan kurangnya sosialisasi .[18]

\section{Kesimpulan}

Untuk mendorong masyarakat DKI Jakarta antuasias dalam memanfaatkan TOGA dan Akupresur secara mandiri, maka perlu dilakukan strategi. Adapun strategi tersebut dengan menyelenggarakan pelatihan bagi petugas kesehatan Puskesmas, kader dan masyarakat dalam memanfaatkan TOGA dan Akupresur, perlombaan penilaian pemanfaatan TOGA dan Akupresur tingkat Nasional dan Provinsi, termasuk DKI Jakarta tiap tahun, menciptakan inovasi melalui penerapan program pemerintah (Smart Government) yang mensosialisasikan pemanfaatan lahan pekarangan sebagai media untuk budidaya tanaman obat, sehingga masyarakat diperkotaan dapat lebih merasakan manfaat 
dari tanaman obat (Smart Living), melakukan sosialisasi pemanfaatan TOGA dan Akupresur secara terus menerus dan berkesinambungan, sehingga masyarakat memahami manfaat TOGA dan Akupresur bagi kesehatan dirinya dan keluarganya dan eningkatkan kelompok asuhan mandiri pemanfaatan TOGA dan Akupresur di tingkat RW, sehingga makin banyak masyarakat yang saling berbagi pengetahuan dan pengalaman tentang manfaat TOGA dan Akupresur.

Acknowledgment

Penelitian ini tidak ada konflik interest.

Daftar Pustaka

1. Diakses Pada Tanggal 8 Februari 2020

2. Sari, L. (2012). Pemanfaatan Obat Tradisional Dengan Pertimbangan Manfaat Dan Keamanannya. Pharmaceutical Sciences And $\begin{array}{lll}\text { Research } & \text { (Psr), } & \text { 3(1), }\end{array}$ Doi:10.7454/Psr.V3i1.3394

3. Keputusan Menteri Kesehatan Republik Indonesia Nomor HK.01.07/Menkes/187/2017 Tentang Formularium Ramuan Obat Tradisional Indonesia.

4. Rencana Strategi Kementerian Kesehatan Tahun 2015-2019 (2017). Kementerian Kesehatan. Jakarta

5. Riskesdas (2018). Badan Penelitian Dan Pengembangan Kesehatan. Kementerian
Kesehatan. Jakarta

[6]Wiku Adisasmito, Phd (2014). Sistem

Kesehatan Edisi Kedua. Divisi Buku Perguruan

Tinggi. Pt Raja Grafindo Persada Jakarta.

6. Sukanta, P. O. (2001). Akupresur \& Minuman Untuk Mengatasi Gangguan Pencernaan. Elex Media Komputindo.

7. Sam Stubblefield. (2017). Survey of complementary and alternative medicine in pediatric inpatient settings. Complementary Therapies in Medicine. Volume 35, December2017,Pages20-

24.https://doi.org/10.1016/j.ctim.2017.08.009Get rights and content

8. Charles W. L. Hill and Gareth R. Jones. (2008). Strategic Management Theory: An Integrated Approach, Ninth Edition. Cengage Learning products are represented in Canada by Nelson Education, Ltd.

9. [9]Dwisatyadini, M. (2017). Pemanfaatan Tanaman Obat Untuk Pencegahan Dan Pengobatan Penyakit Degeneratif.

10. Eriyana, F., Lantara, I., \& Sutrischastini, A. (2019). Evaluasi Asuhan Mandiri Taman Obat Keluarga (Toga) Dan Ketrampilan Akupresur Pada Dinas Kesehatan Kabupaten Ngawi Tahun 2018 (Doctoral dissertation, STIE Widya Wiwaha).

11. Fadmawati, F. (2017). Pengaruh Pendapatan Asli Desa (Padesa), Dana Desa (Dd), Alokasi Dana 
Desa (Add), Dan Jumlah Sarana Kesehatan

Terhadap Alokasi Belanja Desa Bidang

Kesehatan Tahun 2017 (Studi Empiris Di Desa-

Desa Kabupaten Wonogiri). Program Studi

Akuntansi Fakultas Ekonomi Dan Bisnis

Universitas Muhammadiyah Surakarta

12. Formularium Ramuan Obat Tradisional Indonesia (FROTI) (2017). Keputusan Menteri Kesehatan Republik Indonesia Nomor HK.01.07/Menkes/187/2017 Tentang

Formularium Ramuan Obat Tradisional Indonesia.

13. Kementerian Kesehatan (2016). Pedoman Pengembangan Kesehatan Tradisional Melalui Asuhan Mandiri Pemanfaatan Taman Obat Keluarga Dan Keterampilan

14. Laksmiarti, T., \& Nugraheni, W. P. (2013). Analisis Kebijakan Pembiayaan Kesehatan Di Kabupaten Kepulauan Aru (Policy Analysis: Health Financing In Aru Island). Buletin Penelitian Sistem Kesehatan, 16(3 Jul).

15. Naibaho, M. P., Sihombing, M., \& Tarmizi, T. (2014). Analisis Pengaruh Fungsi Perlombaan Desa terhadap Partisipasi Masyarakat dalam Pembangunan Desa di Kecamatan Teluk Mengkudu Kabupaten Serdang Bedagai. JUPIIS: Jurnal Pendidikan Ilmu-Ilmu Sosial, 6(1), 8-13.

16. Nurdiwaty, D., Puspita, E., Kusumaningtyas, D., Winarko, S. P., Tohari, A., Solikah, M. A., \& Faisol, F. (2017). Pemberdayaan Wanita Melalui

Faisol, F. (2017). Pemberdayaan Wanita Melalui
Tanaman Toga Untuk Membantu Meningkatkan Pendapatan Keluarga. Jurnal Abdinus: Jurnal Pengabdian Nusantara, 1(1), 20-27.

17. Yuliani Soerachmad, Hariani. Hubungan Motivasi Dengan Kinerja Kader Posyandu Dikecamatan Bulo Kabupaten Polewali Mandar. Jurnal Kesehatan Masyarakat Vol. 2, No. 2, Nopember 2016 P-ISSN: 2442-8884 / E-Issn: 2541-4542 . Http://Dx.DOI.ORG/10.35329/JKESMAS.V2I2.1 58

18. Kinho, J., Arini, D. I. D., Tabba, S. U. P. R. A. T. M. A. N., Kama, H. A. R. W. I. Y. A. D. D. I. N., Kafiar, Y. E. R. M. I. A. S., Shabri, S. Y. A. M. S. I. R., \& Karundeng, M. C. (2011). Tumbuhan obat tradisional di Sulawesi Utara jilid i. Manado: Balai Penelitian Kehutanan Manado. 